\title{
Safety and effectiveness of tranexamic acid in reduction of post-partum hemorrhage in patients undergoing caesarean section in tertiary care hospital of Southern India
}

\author{
Girish B. L., Shraddha S. G.*, Dwarakanath L.,
}

Department of Obstetrics and Gynaecology, Sri Siddhartha Medical College, Tumkur, Karnataka, India

Received: 13 December 2021

Revised: 08 January 2022

Accepted: 11 January 2022

*Correspondence:

Dr. Shraddha S. G.,

E-mail: shraddhasg15@gmail.com

Copyright: (c) the author(s), publisher and licensee Medip Academy. This is an open-access article distributed under the terms of the Creative Commons Attribution Non-Commercial License, which permits unrestricted non-commercial use, distribution, and reproduction in any medium, provided the original work is properly cited.

\begin{abstract}
Background: Obstetric haemorrhage is a leading cause of premature maternal mortality, accounting for at least 100,000 deaths each year worldwide. Tranexamic acid has been shown to reduce uterine blood loss in non-surgical aspect. The aim of the study is to evaluate the safety and effectiveness of TXA in prevention of post-partum hemorrhage in patients undergoing caesarean delivery and to compare the secondary clinical outcomes.

Methods: In this prospective observational cross-sectional study, 50 pregnant women undergoing CD were selected in random pattern and divided into control and study group of 25 patients each, in the department of obstetrics and gynaecology in Sri. Siddhartha medical college, Tumakuru from November 2019 to October 2021. The study group were given $1 \mathrm{~g}$ of TXA intravenously and the control group did not receive TXA. All the pregnant women received 20 units of oxytocin following delivery.

Results: Mean of the total blood loss in the study group was $67 \%$ less than the control group. Secondary clinical outcomes such as need for blood transfusion, other surgical measures to stop bleeding were comparatively less in study group compared to control groups. To note, no significant difference in duration of hospital stay was found between two groups.

Conclusions: Our study suggests that, a safe dose of $1 \mathrm{~g}$ IV tranexamic acid prior to caesarean section has an effective role in reducing blood loss and significantly improved blood loss-related secondary clinical outcomes with fewer side effects.
\end{abstract}

Keywords: Caesarean section, Tranexamic acid, Post-partum hemorrhage

\section{INTRODUCTION}

Globally post-partum haemorrhage (PPH) is the leading cause of maternal mortality. ${ }^{1}$ Compared to vaginal delivery, women undergoing caesarean delivery (CD) incur the highest risk of $\mathrm{PPH}$ and hemorrhage-related morbidity. ${ }^{2-3}$ Furthermore, evidence suggests that $\mathrm{PPH}$ during CD is occurring more frequently. ${ }^{4}$ The majority of deaths resulting from $\mathrm{PPH}$ occur during the first $24 \mathrm{~h}$ after birth, most of which could be avoided by routine prevention through active management of the third stage of labour and prompt and effective management of PPH, including the use of uterotonics and fluid replacement. Tranexamic acid (TXA), an antifibrinolytic drug, was identified as a promising candidate to be included in recommended packages for treatment of $\mathrm{PPH}$, since it has shown efficacy in reducing blood loss and mortality following surgical trauma. ${ }^{5}$ The WOMAN trial and CRASH-2 trial evaluated that TXA significantly reduces maternal death due to bleeding in women with clinically diagnosed PPH, and that early treatment appears to optimise benefits. ${ }^{6,7}$ 
We designed this study to investigate whether tranexamic acid plus a prophylactic uterotonic agent would be associated with a lower incidence of PPH after CD than the uterotonic agent alone. We also compared secondary clinical outcomes such as incidence of blood transfusion, need for other surgical interventions to stop bleeding and length of hospital stay following CD among two groups.

\section{METHODS}

This was a prospective observational cross-sectional study involving women at 37 to 42 weeks of gestation with singleton pregnancy, irrespective of parity undergoing $\mathrm{CD}$ in department of obstetrics and gynaecology at Sri Siddhartha medical college, Tumakuru, South India from November 2019 to October 2021 were included. Women with obstetric complications (such as severe pre-eclampsia, polyhydramnios, multiple gestation, macrosomia, intra uterine growth retardation, abnormal placenta), gynecological comorbidities (eg Myoma), allergy to TXA, history of thrombo-embolic disorders and severe medical and surgical complications were excluded. Every pregnant woman included in this study was counselled and informed consent was obtained. Fifty pregnant women were randomly categorized into two groups: first, being the study group i.e. twenty five pregnant women who received TXA (1g IV, 15 minutes before the skin incision) and second, being the control group i.e. twenty five pregnant women who did not receive TXA. After the CD, all patients received 1 liter of ringer lactate with 20 units of oxytocin.
After giving skin incision blood was soaked into preweighed 10x10 inches towels and the amniotic fluid was sucked up by vacuum. After removal of placenta bleeding was again considered. Two hours post-partum blood loss was calculated by weighing pre-weighed pads used by the women. Weighing pre-weighed towels soaked into blood and putting them into the following formula=(wet weight-dry weight)/1.05 (1.05 is a constant). Pre and post-operative vitals, hemoglobin $(\mathrm{Hb} \%)$ and packed cell volume (PCV) of all women were monitored. Data was analyzed using statistical package for the social sciences version 25. Continuous variables were summarized using measures of central tendency (mean, standard deviation). Categorical variables were summarized in the form of frequencies and percentages. Appropriate tests of significance (such as, Chi-Square test of significance, unpaired t-test and Paired samples t-test) were used to compare the parameters. The tests were statistically significant if the $\mathrm{p}$ value was less than the cut-off point of 0.05 .

\section{RESULTS}

At baseline, we found no significant difference among parameters such as age, body mass index, mean gravida, vitals, bleeding and clotting parameters between groups (Table 1). Mean total blood loss in study group was significantly less compared to control group 193.4 (107.4) $\mathrm{ml}$ vs. 595.4 (252.7) $\mathrm{ml}$ respectively; $\mathrm{p}<0.0001)$. Mean total blood loss in the study group was $67 \%$ less than the control group (Table 2).

Table 1: Baseline characteristics of participants.

\begin{tabular}{|llll|}
\hline Baseline parameters & $\begin{array}{l}\text { Study group }(\mathbf{N}=\mathbf{2 5}) \\
\text { Mean (SD) }\end{array}$ & $\begin{array}{l}\text { Control group }(\mathbf{N}=\mathbf{2 5}) \\
\text { Mean (SD) }\end{array}$ & P value \\
\hline Age $($ Years) & $25.1(2.2)$ & $26.4(4.1)$ & 0.2 \\
\hline BMI $\left(\mathbf{K g} \mathbf{m}^{\mathbf{2}}\right)$ & $26.1(2.3)$ & $28.5(10.3)$ & 0.2 \\
\hline Mean Gravida & $2.2(0.7)$ & $1.8(0.7)$ & 0.1 \\
\hline Pulse Rate (bpm) & $87(11.5)$ & $84.9(7.0)$ & 0.4 \\
\hline SBP $(\mathbf{m m H g )}$ & $114.0(4.8)$ & $116.4(6.4)$ & 0.2 \\
\hline DBP $(\mathbf{m m H g})$ & $72.4(5.3)$ & $73.1(5.5)$ & 0.6 \\
\hline Bleeding time (sec) & $177.3(43.4)$ & $173.4(34.7)$ & 0.7 \\
\hline Clotting time (sec) & $229.1(36.9)$ & $234.52(31.5)$ & 0.5 \\
\hline Prothrombin time (sec) & $13.6(2.5)$ & $14.6(1.4)$ & 0.08 \\
\hline APTT (sec) & $33.6(3.1)$ & $34.7(3.0)$ & 0.2 \\
\hline INR & $0.9(0.1)$ & $0.9(0.1)$ & 1 \\
\hline
\end{tabular}

In study group, we did not find statistically significant difference in post-operative blood pressure, $\mathrm{Hb}$ and $\mathrm{PCV}$ values compared to preoperative values. In control group, we found significantly lower blood pressure, higher pulse rate, lower $\mathrm{Hb}$ and $\mathrm{PCV}$ values recorded postoperatively compared preoperative measured values (Table 3 ). Need for blood transfusion, other surgical measures to stop bleeding and side effects were comparatively less in study group compared to control groups (Table 4). To note, we found no significant difference in duration of hospital stay between two groups $(\mathrm{p}=0.8)$.

\section{DISCUSSION}

In our study, total blood loss after caesarean section 
varied from $100 \mathrm{ml}$ to $600 \mathrm{ml}$ in the study group and from

$200 \mathrm{ml}$ to $1150 \mathrm{ml}$ in the control group.

Table 2: Effectiveness of tranexamic acid in reduction of blood loss and length of hospital stay.

\begin{tabular}{|lllll|}
\hline Parameters & $\begin{array}{l}\text { Study group (N=25) } \\
\text { Mean (SD) }\end{array}$ & $\begin{array}{l}\text { Control group (N=25) } \\
\text { Mean (SD) }\end{array}$ & P value & $\begin{array}{l}\text { Percentage } \\
\text { reduction }\end{array}$ \\
\hline Total blood loss (ml) & $193.4(107.4)$ & $595.4(252.7)$ & $<0.0001$ & $67 \%$ \\
\hline Hospital stay (days) & $7.3(1.6)$ & $7.4(1.8)$ & 0.8 & NA \\
\hline
\end{tabular}

Table 3: Preoperative and postoperative measurement of parameters within groups.

\begin{tabular}{|lllllll|}
\hline & \multicolumn{2}{l}{ Study group $(\mathbf{N}=\mathbf{2 5})$} & \multicolumn{3}{c|}{ Control group $(\mathbf{N}=25)$} \\
\hline Parameters & Pre-op & Post-op & P value & Pre-op & Post-op & P value \\
\hline Pulse rate $(\mathbf{b p m})$ & $87(11.5)$ & $85.6(8.3)$ & 0.6 & $84.9(7.0)$ & $94.4(9.0)$ & 0.0001 \\
\hline SBP $(\mathbf{m m H g})$ & $114.0(4.8)$ & $112(3.7)$ & 0.1 & $116.4(6.4)$ & $109.1(6.7)$ & 0.0002 \\
\hline DBP $(\mathbf{m m H g})$ & $72.4(5.3)$ & $71.6(6.2)$ & 0.6 & $73.1(5.5)$ & $67.5(6.4)$ & 0.001 \\
\hline HB $(\mathbf{g} \%)$ & $11.9(0.9)$ & $11.7(0.9)$ & 0.4 & $11.8(0.6)$ & $11.1(1.0)$ & 0.001 \\
\hline PCV $(\%)$ & $36.8(5.1)$ & $36.7(5.2)$ & 0.8 & $35.9(1.7)$ & $34.7(2.0)$ & 0.02 \\
\hline
\end{tabular}

Table 4: Blood loss related secondary clinical outcomes.

\begin{tabular}{|lll|}
\hline Intervention & $\begin{array}{l}\text { Study group }(\mathbf{N}=\mathbf{2 5}) \\
\mathbf{N}(\%)\end{array}$ & $\begin{array}{l}\text { Control group }(\mathbf{N}=25) \\
\mathbf{N}(\%)\end{array}$ \\
\hline Blood transfusion & $1(4)$ & $4(16)$ \\
\hline Balloon tamponade & 0 & $2(8)$ \\
\hline Arterial ligation & $1(4)$ & $1(4)$ \\
\hline B-Lynch & 0 & $4(16)$ \\
\hline Hysterectomy and ICU admission & 0 & 0 \\
\hline Total interventions & 2 & 11 \\
\hline
\end{tabular}

Across various studies, it was found to be $367 \mathrm{ml}$ to 583 $\mathrm{ml}$ in the study group and from $464 \mathrm{ml}$ to $851 \mathrm{ml}$ in the control group. The difference between the mean amount of total blood loss is statistically significant between the study group and the control group in each of the studies. ${ }^{8-}$ ${ }^{13}$ Decrease in blood pressure, $\mathrm{Hb}, \mathrm{PCV}$ and increase in pulse rate post operatively in control group was related to increased blood loss in patients during CD.

Blood loss related secondary clinical outcomes after administration of TXA was not studied by many researchers. The present study has identified that there are some cases which do require further management in the form of blood transfusion (4\% in study group and $16 \%$ in control group)/balloon tamponade ( $0 \%$ in study group and $8 \%$ in control group)/arterial ligation (4\% in study group and $4 \%$ in control group)/B-lynch suturing (0\% in study group and $4 \%$ in control group). No patient required Hysterectomy and ICU admission in our study. Similarly, study conducted by Nivedhana et al showed that blood transfusion was needed for $3 \%$ of study group and $9 \%$ of control group. ${ }^{9}$ Gohel et al and Naganagoudaru et al did not report any cases of hysterectomy just like the present study. ${ }^{10-12}$ In our study, prophylactic use of TXA at CD had a biologic effect, in that the estimated blood loss was significantly lower among women who received the drug than among those who did not receive (the mean between-group difference in blood loss was 67\%); this difference resulted from a significantly smaller decrease in hematocrit and hemoglobin from before surgery to after surgery in the study group than in the control group. Our results are similar to findings of meta-analyses of summary data from single-center, randomized trials, which have shown that TXAadministration at CD resulted in significantly less mean estimated blood loss, less frequent use of additional uterotonic agents, and less frequent transfusions than placebo or no treatment. ${ }^{13-18}$ In contrast, study by Sentilhes et al did not show significant betweengroup differences in the blood loss related secondary clinical outcomes. ${ }^{19}$ Most common side effects noted in the present study receiving TXA were gastro-intestinal (nausea, vomiting, diarrhea) and giddiness. No thrombotic complication was encountered in study participants. Similarly vomiting and headache was reported by the pregnant women who participated in the similar study conducted by Sathyavathi et al. ${ }^{20}$ Our study had some limitations. It was a single center based open labelled study conducted using fixed dose of tranexamic acid regardless the body weight (1g TXA to all pregnant females in study group). Our calculating method for blood loss did not discriminate between intraoperative and postoperative bleeding. The study was not powered to detect potentially meaningful differences in the risk of secondary clinical outcomes, such as transfusion. 


\section{CONCLUSION}

To conclude, among women who underwent cesarean delivery and received a prophylactic uterotonic agent, tranexamic acid administration resulted in a significantly lower postpartum blood loss and significant improvement in blood loss-related secondary clinical outcomes.

Funding: No funding sources

Conflict of interest: None declared

Ethical approval: The study was approved by the Institutional Ethics Committee

\section{REFERENCES}

1. Say L, Chou D, Gemmill A, Tunçalp Ö, Moller AB, Daniels J, et al. Global causes of maternal death: a WHO systematic analysis. Lancet Glob Health 2014; 2:e323-33.

2. Al-Zirqi I, Vangen S, Forsen L, Stray-Pedersen B. Effects of onset of labor and mode of delivery on severe postpartum hemorrhage. Am J Obstet Gynecol. 2009;201:273 e1-9.

3. Bateman BT, Berman MF, Riley LE, Leffert LR. The epidemiology of postpartum hemorrhage in a large, nationwide sample of deliveries. Anesth Analg. 2010; 110:1368-73.

4. Callaghan WM, Kuklina EV, Berg CJ. Trends in postpartum hemorrhage: United States, 19942006. Am J Obstet Gynecol. 2010;202:353 e1-6.

5. Perel $\mathrm{P}$, Ker $\mathrm{K}$, Morales Uribe $\mathrm{CH}$, Roberts I. Tranexamic acid for reducing mortality in emergency and urgent surgery. Cochrane Database Syst Rev. 2013;1:CD010245.

6. WOMAN Trial Collaborators. Effect of early tranexamic acid administration on mortality, hysterectomy, and other morbidities in women with post-partum haemorrhage (WOMAN): an international, randomised, double-blind, placebocontrolled trial. Lancet. 2017;389:2105-16.

7. CRASH-2 trial collaborators. Effects of tranexamic acid on death, vascular occlusive events, and blood transfusion in trauma patients with significant haemorrhage (CRASH-2): a randomised, placebocontrolled trial. Lancet. 2010;376:23-32.

8. Sahu J, Mishra N. Role of intravenous tranexamic acid in reducing blood loss during caesarean section: Study at tribal dominated area hospital in Chhattisgarh, India. J Obstet Gynaecol Res. 2019; 45(4):841-8.

9. Nivedhana AP, Indu NR, Jalakandan B. Does prophylactic tranexamic acid reduce blood loss in Indian women following vaginal delivery?. Int J Reprod Contracept Obstet Gynecol. 2021;10:497-504.
10. Gohel M, Patel P, Gupta A, Desai P. Efficacy of tranexamic acid in decreasing blood loss during and after cesarean section: A randomized case controlled prospective study. J Obstet Gynecol India. 2007; 57(3):227-30.

11. Bhatia SK, Deshpande H. Role of tranexamic acid in reducing blood loss during and after caesarean section. Med J DY Patil Univ. 2015;8:21-5.

12. Naganagoudaru R, Vinaya G. Tranexamic acid for the treatment of postpartum hemorrhage: placebo controlled study. Int J Reprod Contracept Obstet Gynecol. 2017;6:3071-5.

13. Yehia A, Koleib M, Abdelazim I, Atik A. Tranexamic acid reduces blood loss during and after cesarean section: A double blinded, randomized, controlled trial. Asian Pacific J Reprod. 2014;3(1):53-6.

14. Novikova N, Hofmeyr GJ, Cluver C. Tranexamic acid for preventing postpartum haemorrhage. Cochrane Database Syst Rev. 2015;(6):CD007872.

15. Alam A, Choi S. Prophylactic use of tranexamic acid for postpartum bleeding outcomes: a systematic review and meta-analysis of randomized controlled trials. Transfus Med Rev. 2015;29:231-41.

16. Simonazzi G, Bisulli M, Saccone G, Moro E, Marshall A, Berghella V. Tranexamic acid for preventing postpartum blood loss after cesarean delivery: a systematic review and meta-analysis of randomized controlled trials. Acta Obstet Gynecol Scand. 2016;95:28-37.

17. Li C, Gong Y, Dong L, Xie B, Dai Z. Is prophylactic tranexamic acid administration effective and safe for postpartum hemorrhage prevention? A systematic review and meta-analysis. Medicine (Baltimore). 2017;96(1):e5653.

18. Sivakumar H, Peyton PJ. Poor agreement in significant findings between meta-analyses and subsequent large randomized trials in perioperative medicine. Br J Anaesth. 2016;117:431-41.

19. Sentilhes L, Winer N, Azria E, Sénat MV, Le Ray C, Vardon D. Tranexamic acid for the prevention of blood loss after vaginal delivery. N Engl J Med. 2018;379(8):731-42.

20. Satyavathi GAL, Chandrika K. Efficacy of tranexamic acid in preventing postpartum haemorrhage in vaginal delivery. Int $\mathbf{J}$ Reprod Contracept Obstet Gynecol. 2019;8(9):1-7.

Cite this article as: Girish BL, Shraddha SG, Dwarakanath L. Safety and effectiveness of tranexamic acid in reduction of post-partum hemorrhage in patients undergoing caesarean section in tertiary care hospital of Southern India. Int J Reprod Contracept Obstet Gynecol 2022;11:513-6. 